\title{
Ecosystem respiration and its components from a Carex meadow of Poyang Lake during the drawdown period
}

\author{
Qiwu $\mathrm{Hu}{ }^{\mathrm{a}}$, Qin $\mathrm{Wu}^{\mathrm{a}}$, Bo Yao ${ }^{\mathrm{c}}$, Xingliang $\mathrm{Xu}{ }^{\mathrm{b}}{ }^{*}$ * \\ ${ }^{a}$ Key Laboratory of Poyang Lake Wetland and Watershed Research, Ministry of Education, Jiangxi Normal University, No. 99, Ziyang Road, Nanchang \\ 330022, China \\ ${ }^{\mathrm{b}}$ Key Laboratory of Ecosystem Network Observation and Modelling, Institute of Geographic Sciences and Natural Resources Research, Chinese Academy of \\ Sciences, 11A, Datun Road, Chaoyang District, Beijing 100101, China \\ ${ }^{\mathrm{c}}$ Science and Technology College, Jiangxi Normal University, 437, Beijing Road, Nanchang 330027, China
}

\section{H I G H L I G H T S}

- Ecosystem respiration and its components were mainly controlled by temperature.

- $Q_{10}$ values varied widely with time and among ecosystem respiratory components.

- Summer flood duration could largely alter drawdown period carbon sink intensity.

\section{A R T I C L E I N F O}

\section{Article history:}

Received 5 April 2014

Received in revised form

27 September 2014

Accepted 28 October 2014

Available online 30 October 2014

\section{Keywords:}

Poyang lake

Carex meadow

Ecosystem respiratory component

Temperature sensitivity

Carbon sink

\begin{abstract}
A B S T R A C T
Little is known about the components of ecosystem respiration from a subtropical littoral wetland with dramatic annual inundation dynamics. In this study, we investigated ecosystem respiration and its components in a Poyang lake Carex meadow during the drawdown periods from May 2009 to June 2011. Both ecosystem respiration and its components showed clear temporal variation pattern, with temperature being the dominant control. Ecosystem respiration ranged from 98.01 to $1359.25 \mathrm{mg} \mathrm{CO}_{2}$ $\mathrm{m}^{-2} \mathrm{~h}^{-1}$. Shoot and root respiration contributed approximately $36 \%$ and $26 \%$ to the ecosystem respiration, respectively, whereas microbial respiration accounted for $38 \%$ of the ecosystem respiration. The ratio of total soil respiration to ecosystem respiration varied from 0.45 to 0.90 , depending on growing season stages. Their $Q_{10}$ values ranged from 1.72 to 2.51 , with the maximum for shoot respiration and the minimum for microbial respiration. In addition, the $Q_{10}$ values varied with time and among ecosystem respiratory components and hence could not be treated as a constant. None of the respiration measurements was significantly related to soil moisture, suggesting that soil moisture was not a limiting environmental factor for respiratory activity during the drawdown periods in this meadow. The Carex meadow acted as strong carbon sink during the drawdown periods due to double growing seasons, but the previous summer flood duration could substantially alter carbon sink intensity in the following drawdown period. The total carbon sink of the littoral zone of Poyang Lake during drawdown periods

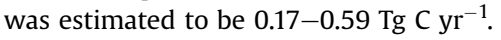

() 2014 Elsevier Ltd. All rights reserved.

\section{Introduction}

Wetlands cover only about $5-8 \%$ of the terrestrial land surface (Mitsch and Gosselink, 2007), but they are estimated to account for $20-30 \%$ of the global soil organic carbon pool (Roulet, 2000; Bridgham et al., 2006). High productivity and waterlogged conditions make many wetlands significant carbon sinks (Bernal and

\footnotetext{
* Corresponding author.

E-mail addresses: xuxl@igsnrr.ac.cn, xuxingl@hotmail.com (X. Xu).
}

Mitsch, 2012). A large number of carbon studies have been conducted in boreal peatlands (Gorham, 1991; Roulet et al., 2007; Lund et al., 2010; Fan et al., 2013). By comparison, the biogeochemistry in tropical and subtropical wetlands was still poorly understood (Mitsch et al., 2010). A recent study has suggested global wetlands currently had net carbon retention of $118 \mathrm{~g} \mathrm{C} \mathrm{m}^{-2} \mathrm{yr}^{-1}$, but most of that carbon sequestration occurred in tropical and subtropical wetlands (Mitsch et al., 2012). Subtropical shallow lakes may present differential conditions that make them ecologically distinct from other types of lakes (They et al., 2013). Due to the shallow water depths and the favorable temperature regime, littoral plants 
can colonize extensive areas and grow continuously almost throughout the year. The littoral zone of a lake comprises a biogeochemically active terrestrial-aquatic interface where carbon dioxide and methane are exchanged with the atmosphere, and organic carbon is transferred to the lake (Larmola et al., 2003). Because of frequent water level fluctuation, many studies have demonstrated that littoral zones are 'hot spots' for carbon cycling and thus cannot be neglected in whole-lake and regional estimates of carbon budgets (Hirota et al., 2007; Zhu et al., 2010; Yang et al., 2014). Therefore, there is an urgent need for the knowledge of carbon fluxes from various littoral wetlands, especially in largely unexplored subtropical lakes.

Previous studies have suggested respiration, rather than gross primary production, was the main determinant in controlling carbon balance of ecosystems (Valentini et al., 2000). The main components of ecosystem respiration are autotrophic respiration (Ra) from plants and heterotrophic respiration ( $\mathrm{Rh}$ ) from microbial decomposition of soil organic matter. The dynamics of the two components may be controlled by different environmental factors, such as temperature, water availability, or photosynthetic activity. In addition, the sensitivity of $\mathrm{Ra}$ and $\mathrm{Rh}$ to temperature largely differs, exhibiting different $Q_{10}$ values (Boone et al., 1998; Rey et al., 2002; Zhou et al., 2009a). Hence, partitioning ecosystem respiration into autotrophic and heterotrophic components is crucial for better understanding their differential responses to climate change. Moreover, knowledge of heterotrophic flux is required to calculate net ecosystem production and for comparison with net ecosystem $\mathrm{CO}_{2}$ exchange derived from eddy covariance techniques. To date, studies on these respiratory components have mainly focused on terrestrial ecosystems, and few data are available for wetland ecosystems.

In China, wetland carbon flux studies were concentrated in cold and temperate regions, such as alpine wetlands on the Tibetan Plateau (Hirota et al., 2006; Chen et al., 2009; Zhao et al., 2010), and marshlands in Sanjiang Plain (Ding et al., 2005; Song et al., 2011; Wang et al., 2013). However, the data were rarely available in warm regions (Xu and Tian, 2012; Yu et al., 2013). Poyang Lake is the largest freshwater lake in China. It is a typical subtropical shallow water lake characterized by drastic annual and interannual water level fluctuation. The lake comprises perennial water body and seasonally flooding littoral zones. Littoral zones in Poyang Lake cover over $938 \mathrm{~km}^{2}$, approximately $30 \%$ of the total lake area (Hu et al., 2010). In summer flood season, the littoral areas are completely inundated and become part of the large water body. When the flood recedes in autumn, the drawdown areas emerge again. Therefore, the littoral areas experience an annual drawdown period from the previous flood ending to the next year flood initiation. In recent years, climate change and the operation of the Three Gorges Dam have largely altered the hydrological regime of Poyang Lake, resulting in reduction of summer flooding and extension of winter drawdown periods (Zhang et al., 2012). As a result, soil carbon increases the exposure to aerobic decomposition, potentially leading to more carbon loss from the littoral areas. Carex is the most dominant species in Poyang Lake littoral meadow. During the drawdown period, Carex is uniquely characterized by two growing seasons, with one in spring and the other occurring after summer flood (Hu et al., 2010). Double growing seasons of Carex may greatly contribute to carbon sequestration in the littoral meadow. However, the optimum temperature and soil water regime during drawdown period may result in substantial carbon emission. Nevertheless, carbon fluxes in these widely distributed littoral meadows of Poyang Lake were poorly documented, except our two previous studies showing short-term methane and carbon dioxide emission (Hu et al., 2011a, b). Consequently, to quantify carbon fluxes and temperature sensitivity of various respiratory processes during the drawdown periods is essential for understanding response of Poyang Lake littoral meadows to ongoing climate warming and hydrological change. Therefore, the objectives of this study were to (1) separate ecosystem respiration into various component fluxes, and distinguish their temperature sensitivities, and (2) evaluate carbon balance of Carex meadow of the Poyang Lake during the drawdown period.

\section{Materials and methods}

\subsection{Study area}

This study was conducted in the Nanji Wetlands National Nature Reserve in the south of Poyang Lake, located in Xinjian County $\left(28^{\circ} 53^{\prime} 35^{\prime \prime} \mathrm{N}, 116^{\circ} 19^{\prime} 11^{\prime \prime} \mathrm{E}, 15 \mathrm{~m}\right.$ above sea level), Jiangxi Province, China (Fig. 1). Characterized by a typical subtropical humid monsoon climate, the area's mean annual air temperature was $17.6^{\circ} \mathrm{C}$, with mean January temperature of $5.1^{\circ} \mathrm{C}$ and a July mean of $29.5{ }^{\circ} \mathrm{C}$. The annual precipitation ranged from $1450 \mathrm{~mm}$ to $1550 \mathrm{~mm}$, most of which falls from April to June.

The Poyang Lake comprises perennial water body and seasonally flooding littoral areas. In summer flood season, the littoral areas are completely inundated and become part of the large water body (Fig. 1b). When the flood recedes in autumn, these areas emerge again (Fig. 1a). The periodic flood areas experience an annual drawdown period from the previous flood ending to the next year flood initiation. The flood season varied from two to five months, depending on both local precipitation and hydrologic regime of the Yangzi River. Correspondingly, the drawdown periods ranged from seven to ten months (Liu et al., 2006).

During the drawdown period, the meadows are dominated by Carex species, showing two unique growing seasons, with one in spring and the other occurring after the summer flood. Carex cinerascens is the dominant species with the coverage over 95\%, companied only by a few species such as Potrntilla limprichtii, Cardamine lyrata and Polygonum hydropiper. The soil is classified as meadow soil, corresponding to inceptisols in American soil taxonomy (Shi et al., 2004). Main characteristics of the Carex meadow were shown in Table 1.

\subsection{Experimental design}

Three treatments were set in a typical Carex meadow, including ecosystem respiration ( $R e$ ), total soil respiration (Rs) and microbial respiration $(\mathrm{Rh})$, respectively. For each treatment, we first inserted a square-based stainless steel frame into soil as sampling plots. The frame was $0.5 \mathrm{~m}$ length $\times 0.5 \mathrm{~m}$ width $\times 0.15 \mathrm{~m}$ depth for Re and Rs, but $0.5 \mathrm{~m}$ length $\times 0.5 \mathrm{~m}$ width $\times 0.4 \mathrm{~m}$ depth for $\mathrm{Rh}$ to cut off old roots and prevent new roots encroachment. Subsequently, we maintained aboveground plant parts within the base frame for Re treatment, but removed aboveground parts for Rs and Rh treatments one day before flux measurement. The sampling plots for Re and $\mathrm{Rh}$ treatments were maintained during the entire carbon flux measurements, whereas the plots for the Rs treatment were replaced in each growing season to minimize effects of aboveground biomass removal. $\mathrm{CO}_{2}$ flux from Re and Rs treatments were regarded as ecosystem respiration and total soil respiration, respectively.

Previous studies have suggested $\mathrm{CO}_{2}$ efflux could represent soil microbial respiration after several months by cutting off old plant roots and preventing new roots encroachment (Hanson et al., 2000; Zhou et al., 2007). In this study, $\mathrm{CO}_{2}$ flux from the Rh treatment was regarded as soil microbial respiration when ratio of flux rate from the Rh treatment to from the Rs treatment declined substantially after about 9 months. As a result, various fluxes of ecosystem 


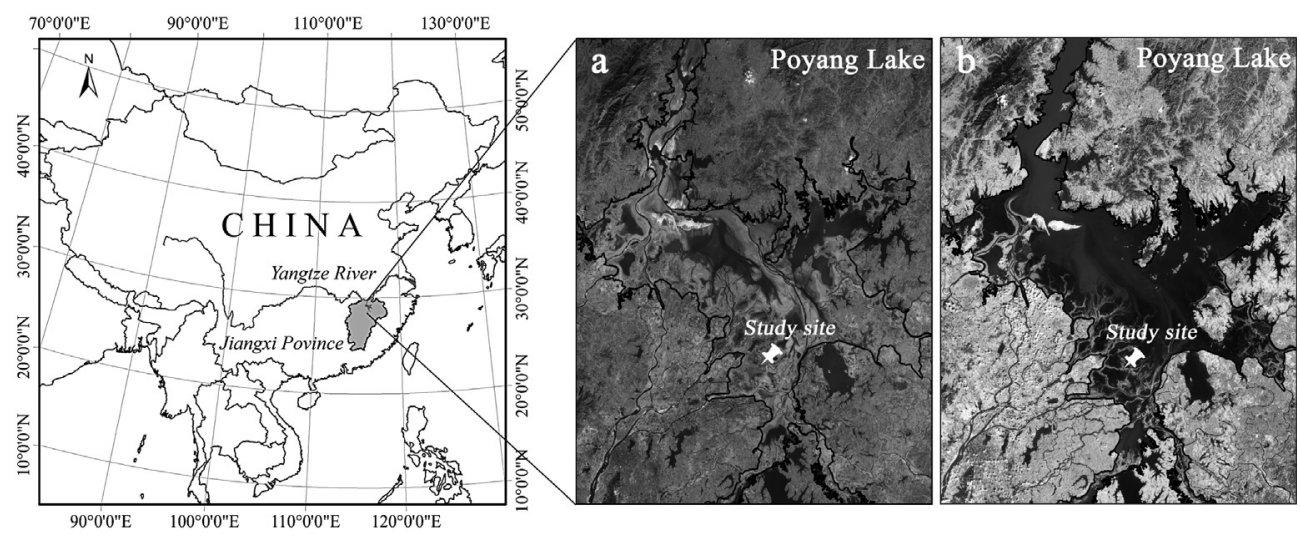

Fig. 1. The location of sampling site, the image of drawdown period (a) and flood period (b) of Poyang Lake.

components could be calculated as their difference. The area of each sampling plot was $0.25 \mathrm{~m}^{2}$ and triplicate plots were randomly located for each treatment. $\mathrm{CO}_{2}$ flux measurements started several days after the base-frame installation to minimize soil disturbance.

\subsection{Gas sampling and analysis}

$\mathrm{CO}_{2}$ flux was measured using static closed chamber-GC techniques (Wang and Wang, 2003) during the drawdown period from May 18, 2009 to June 12, 2011. The sample chambers were made of thin stainless steel, comprising two parts: a top-chamber and a base-frame. The top chamber $(0.5 \mathrm{~m} \times 0.5 \mathrm{~m} \times 0.5 \mathrm{~m})$ was equipped with two fans inside the top, powered by a $12 \mathrm{~V}$ direct currency. The base-frame had a groove on the upper end, which, during sampling, was filled with water to avoid gas exchange inside and outside of the chamber. Gas sampling uses $100 \mathrm{ml}$ syringe at time intervals of $0 \mathrm{~min}, 10 \mathrm{~min}, 20 \mathrm{~min}$ and $30 \mathrm{~min}$, respectively. Samples were taken between 9:00 and 11:00 h, twice or three times a month. Gas samples were transferred to sampling air bags and brought to the laboratory for $\mathrm{CO}_{2}$ analyzing by a gas chromatograph (GC) (Agilent 4890D, Agilent Technologies). The GC was equipped with a flame-ionization detector (FID) and a stainless steel column (Packed with Porapak Q, 60-80 mesh, $2 \mathrm{~mm}$ diameter $\times 200 \mathrm{~mm}$ length). Before detected by FID, $\mathrm{CO}_{2}$ must pass a converter (Nickel catalyst), where it was converted into $\mathrm{CH}_{4}$. FID and column temperatures were maintained at $230{ }^{\circ} \mathrm{C}$ and $55^{\circ} \mathrm{C}$, respectively. $\mathrm{N}_{2}$ acted as carrier gas with a flow rate of $30 \mathrm{ml} \mathrm{min}^{-1}$. Analysis precision of samples was $\pm 1.29 \mathrm{ppmv}$ and the coefficient of variation (CV) ranged from $0.07 \%$ to $0.20 \%$. The GC configurations for analyzing $\mathrm{CO}_{2}$ and the methods for calculating the gas flux were the same as described by Wang and Wang (2003).

\subsection{Environmental factors}

When gas sampling, ambient air temperature, soil temperature at $5 \mathrm{~cm}$ depth, and headspace air temperature of sample chambers were measured simultaneously by a portable thermometer (JM624) and soil water content at $10 \mathrm{~cm}$ depth was determined by moisture meter (TDR300). An automatic air temperature meter (HOBO Pro, Onset Company, USA) was set up at the sampling site to record daily air temperature at an interval of $2 \mathrm{~h}$.

Plant biomass was measured by clipping vegetation samples from three representative $0.25 \mathrm{~m}^{2}$ quadrats about every 30 days in the dry season. The first biomass measurement in spring and autumn was conducted in early February and 10 days after the drawdown area emergence, respectively. Plant materials were divided into living and dead parts before they were oven dried at
$70{ }^{\circ} \mathrm{C}$ for $48 \mathrm{~h}$ and then weighed. Root biomass was measured by collecting soil samples from depths of $0-40 \mathrm{~cm}$ from three $0.25 \mathrm{~m} \times 0.25 \mathrm{~m}$ quadrats, which were co-located with the above ground biomass measurement quadrat. As there is currently no effective method available for separating live and dead roots in field investigation, we distinguished the roots with visual identification. It is reliable for most broad-leaved herbaceous species with largesized roots, but there might be minor errors for small-sized roots.

\subsection{Data analysis}

We estimated aboveground NPP for each growing season as the maximum aboveground biomass carbon content, whereas belowground NPP as the difference between the maximum and minimum belowground biomass carbon content. Then the total NPP was calculated by the sum of aboveground and belowground NPP.

Daily respiratory $\mathrm{CO}_{2}$ fluxes were estimated based on the exponential relations between air temperature and $\mathrm{CO}_{2}$ fluxes in the measurement days. The total respiratory carbon emission during drawdown periods was the sum of daily carbon emissions. Carbon balance during the drawdown periods was then estimated as the difference between NPP and total soil carbon emission as heterotrophic respiration.

We assessed sensitivity of mean $\mathrm{CO}_{2}$ flux to temperature by fitting exponential function to the data from individual treatments (Zhou et al., 2007).

$R=a e^{b t}$

where $R$ is the mean $\mathrm{CO}_{2}$ flux, $t$ is the temperature, $\mathrm{a}$ is the intercept of $\mathrm{CO}_{2}$ flux when temperature is zero, and $b$ represents the temperature sensitivity of $\mathrm{CO}_{2}$ flux. The $b$ values were used to calculate temperature sensitivity indicator $\left(Q_{10}\right)$, which describes the change in fluxes over a $10^{\circ} \mathrm{C}$ increase in temperature, by

$Q_{10}=\exp (10 b)$

\subsection{Statistical analysis}

One-way ANOVA was used to test differences in environmental variables. Exponential and linear regression models were used to describe the relations between respiration and temperature, moisture as well as plant biomass. Data analysis and plotting were processed using SigmaPlot 10.0 (SPSS Inc., Chicago, USA). All statistical analysis was performed using SPSS 11.5 (SPSS Inc., Chicago, USA). All significant difference was considered at a $P<0.05$ level. 
Table 1

Main characteristics of sampling sites.

\begin{tabular}{ll}
\hline Characteristics & Carex meadow \\
\hline Dominant species & Carex cinerascens \\
Canopy height $(\mathrm{cm})$ & $30-60$ \\
Plant total carbon $(\%)$ & $42.5 \pm 0.5$ \\
Soil pH $(0-30 \mathrm{~cm})$ & $5.4 \pm 0.6$ \\
Soil Eh $(0-30 \mathrm{~cm}) / \mathrm{mV}$ & $171.7 \pm 16.6$ \\
Soil bulk density $\left(\mathrm{g} \mathrm{cm}^{-3}\right)$ & \\
$0-15 \mathrm{~cm}$ & $1.03 \pm 0.12$ \\
$15-30 \mathrm{~cm}$ & $1.37 \pm 0.09$ \\
Soil organic carbon (\%) & $1.97 \pm 0.22$ \\
$0-15 \mathrm{~cm}$ & $0.79 \pm 0.23$ \\
$15-30 \mathrm{~m}$ & \\
Total nitrogen $\%)$ & $0.173 \pm 0.017$ \\
$0-15 \mathrm{~cm}$ & $0.084 \pm 0.010$ \\
$15-30 \mathrm{~m}$ & $11.1 \pm 0.3$ \\
Soil C/N & $9.3 \pm 1.4$ \\
$0-15 \mathrm{~cm}$ & \\
$15-30 \mathrm{~m}$ & 220 (From September 6, 2009 to April 14, 2010) \\
Drawdown duration(d) & 257 (From October 2, 2010 to June 16, 2011) \\
$2009-2010$ &
\end{tabular}

Data was shown as mean \pm standard deviation.

\section{Results}

\subsection{Abiotic factors and carbon dioxide fluxes}

The mean July air temperature in 2009 and 2010 (29.6 and $\left.29.7^{\circ} \mathrm{C}\right)$ was very close to the long-term average value $\left(29.5^{\circ} \mathrm{C}\right)$. The mean January air temperature in 2010 and 2011 was $7.2{ }^{\circ} \mathrm{C}$ and $2.4{ }^{\circ} \mathrm{C}$, respectively, which indicated a relative large inter-annual winter temperature variation (Fig. 2A). During the drawdown period flux days, air temperature ranged from $1.2{ }^{\circ} \mathrm{C}$ to $31.8^{\circ} \mathrm{C}$. Soil temperature at $5 \mathrm{~cm}$ depth varied from $3.3^{\circ} \mathrm{C}$ to $28.1^{\circ} \mathrm{C}$ (Fig. 2B). The mean soil temperature for Re, Rs and Rh treatment was $16.0,16.5$ and $16.9{ }^{\circ} \mathrm{C}$. Soil moisture at $10 \mathrm{~cm}$ depth ranged from $47.8 \%$ to

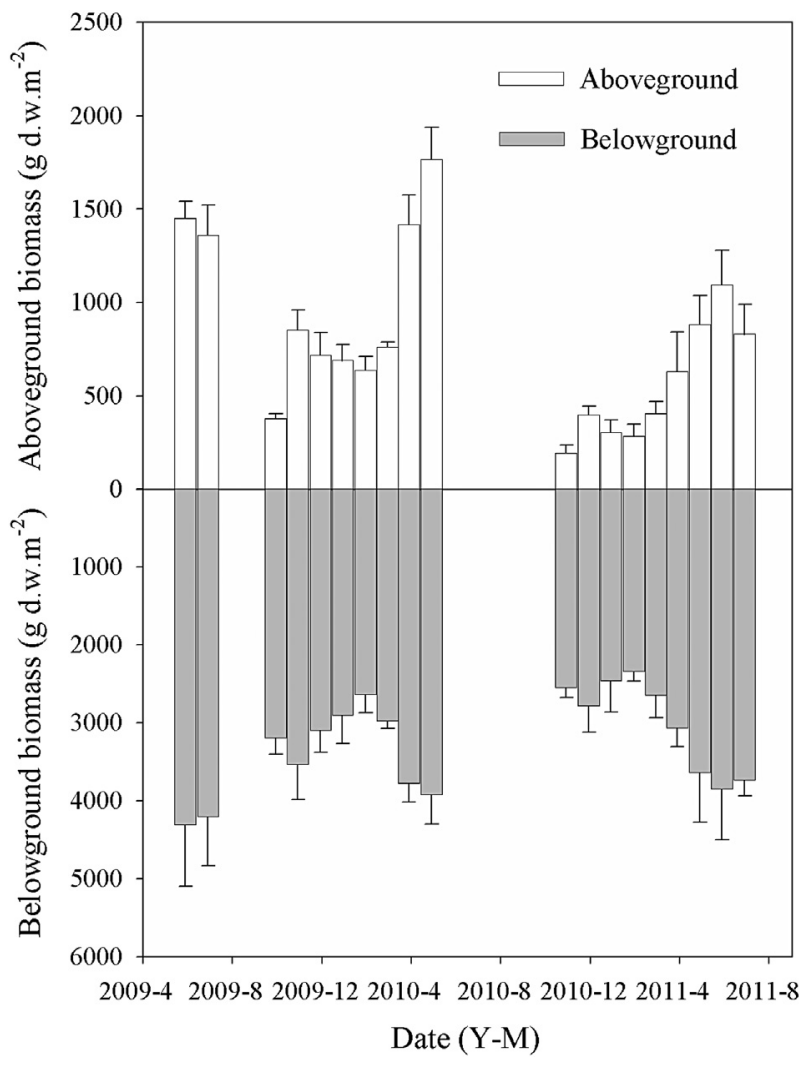

Fig. 3. Monthly aboveground and belowground plant biomass of Carex meadow.

64.5\%, with mean of 55.1\% (Fig. 2C). Neither soil temperature nor moisture significantly differed among the three treatments $(P>0.05)$.

$\mathrm{CO}_{2}$ fluxes from Re, Rs and Rh treatments showed similar temporal variation patterns. It reached the maximum at peak growing
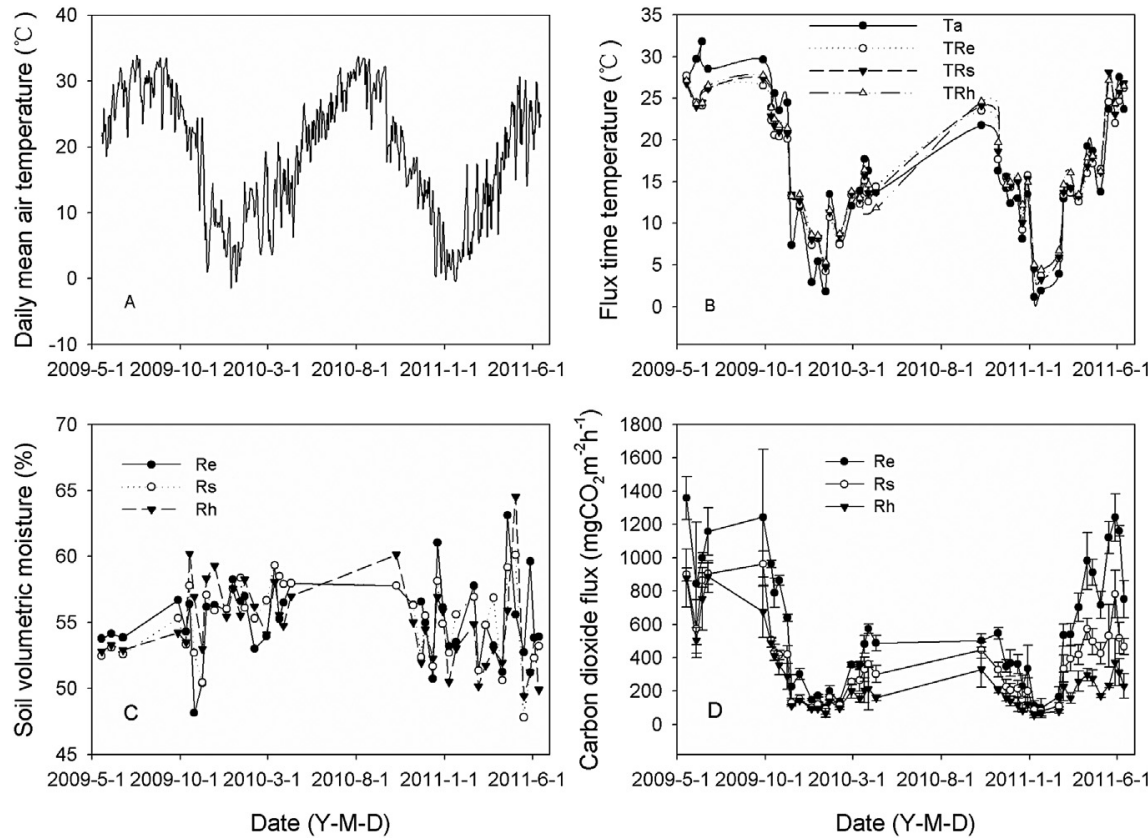

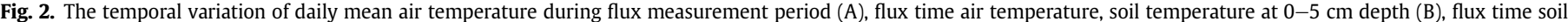

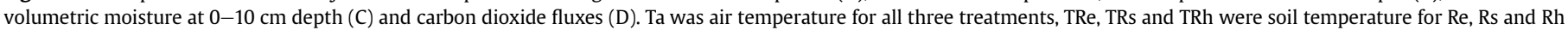
treatment, respectively. Soil moisture on June 14, 2009 was excluded in the figure $C$ as water table reached $1.8 \mathrm{~cm}$ above soil surface. 
periods and minimum in January when plants were nearly dormant (Fig. 2D). The flux rate ranged from 98.01 to $1359.25 \mathrm{mg} \mathrm{CO}_{2}$ $\mathrm{m}^{-2} \mathrm{~h}^{-1}$ for the Re treatment, but 81.59-960.94 $\mathrm{mg} \mathrm{CO}_{2} \mathrm{~m}^{-2} \mathrm{~h}^{-1}$ for the Rs treatment and 56.13-886.45 $\mathrm{mg} \mathrm{CO}_{2} \mathrm{~m}^{-2} \mathrm{~h}^{-1}$ for the $\mathrm{Rh}$ treatment, respectively. Ratio of flux rate from the Rs treatment to from the Re treatment varied from 0.45 to 0.90 , with mean of 0.66 . The flux rate ratio of the Rh treatment to the Rs treatment ranged from 0.40 to 0.98 , and declined substantially from previous averaged 0.86 to 0.60 in March 2010. The lower ratio was maintained in the following flux measurement days, which suggested $\mathrm{CO}_{2}$ flux
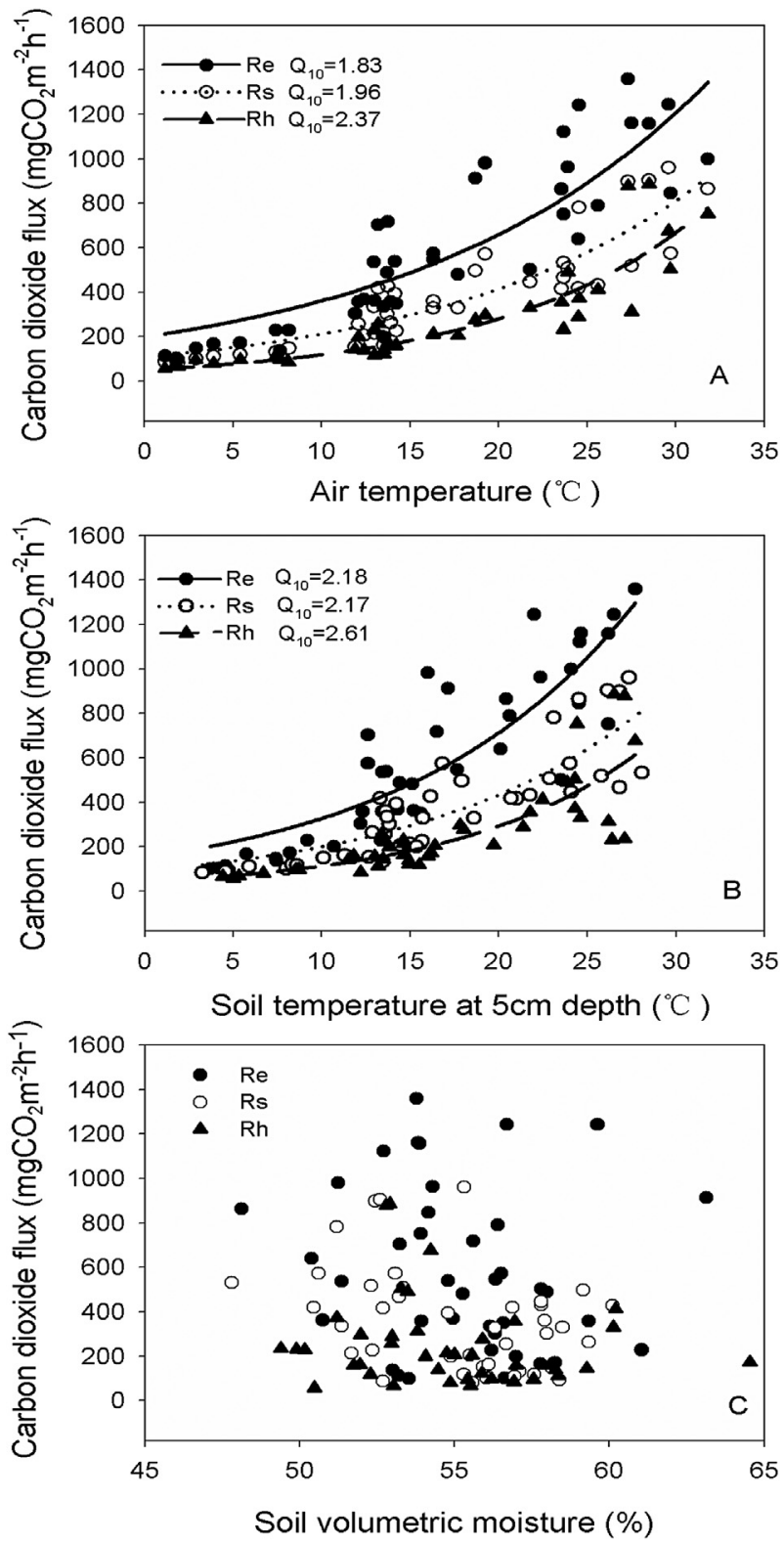

Fig. 4. Dependency of $\mathrm{CO}_{2}$ flux on air temperature (A) and soil temperature at $5 \mathrm{~cm}$ depth (B) measured during the period from May 2009 to June 2011. The equations for predicting $\mathrm{CO}_{2}$ flux from air temperature were $y=197.88 \mathrm{e}^{0.0602 \mathrm{x}}, R^{2}=0.75$ for Re treatment, $y=108.12 \mathrm{e}^{0.0672 \mathrm{x}}, R^{2}=0.80$ for Rs treatment and $y=49.94 \mathrm{e}^{0.0864 \mathrm{x}}$ $R^{2}=0.78$ for $\mathrm{Rh}$ treatment. The equations from soil temperature were $y=150.33 \mathrm{e}^{0.0778 \mathrm{x}}, R^{2}=0.75$ for Re treatment, $y=91.83 \mathrm{e}^{0.0776 \mathrm{x}}, R^{2}=0.72$ for Rs treatment and $y=42.91 \mathrm{e}^{0.0961 x}, R^{2}=0.64$ for Rh treatment. $P<0.001$ was applied for all regression coefficients and intercepts. Soil moisture was not related to $\mathrm{CO}_{2}$ fluxes (C). from the Rh treatment could be regarded as soil microbial respiration since March, 2010.

\subsection{Plant biomass}

Both aboveground and belowground biomass showed clear seasonal variation patterns. In spring growing season, plant biomass peaked in April or May, whereas in autumn growing season after summer flood, it reached the maximum in the October or November (Fig. 3). Biomass was much higher in spring than in autumn. For example, the maximum total biomass was 5684.5 and 3179.8 g dry weight (d.w.) $\mathrm{m}^{-2}$ in spring and autumn in 2010 , respectively. The ratio of belowground to aboveground biomass differed in growing stages, ranging from 2.2 to 13.3. Moreover, aboveground biomass largely differed in the two continued drawdown periods which ranged from September 2009 to April 2010 and October 2010 to June 2011, respectively. The maximum aboveground biomass in the former drawdown period was 851.6 and $1765.4 \mathrm{~g} \mathrm{~d} \mathrm{w} \mathrm{m}^{-2}$ for autumn and spring growing season, whereas the counterparts in the latter drawdown period were 396.5 and $1093.6 \mathrm{~g} \mathrm{~d} \mathrm{w} \mathrm{m}^{-2}$, respectively.

\subsection{Effects of environmental variables on $\mathrm{CO}_{2}$ fluxes}

Air and soil temperatures were both significantly positively correlated with $\mathrm{CO}_{2}$ flux rates of the three treatments. The dependency of $\mathrm{CO}_{2}$ fluxes on temperature changes could be best described by exponential equation $\left(R=a e^{b t}\right)$. Changes in air temperature could explain $75 \%-80 \%$ of the variation in $\mathrm{CO}_{2}$ fluxes (Fig. 4A). The $Q_{10}$ value was higher for the Rh treatment than for Re and Rs treatments. By comparison, all three treatments showed

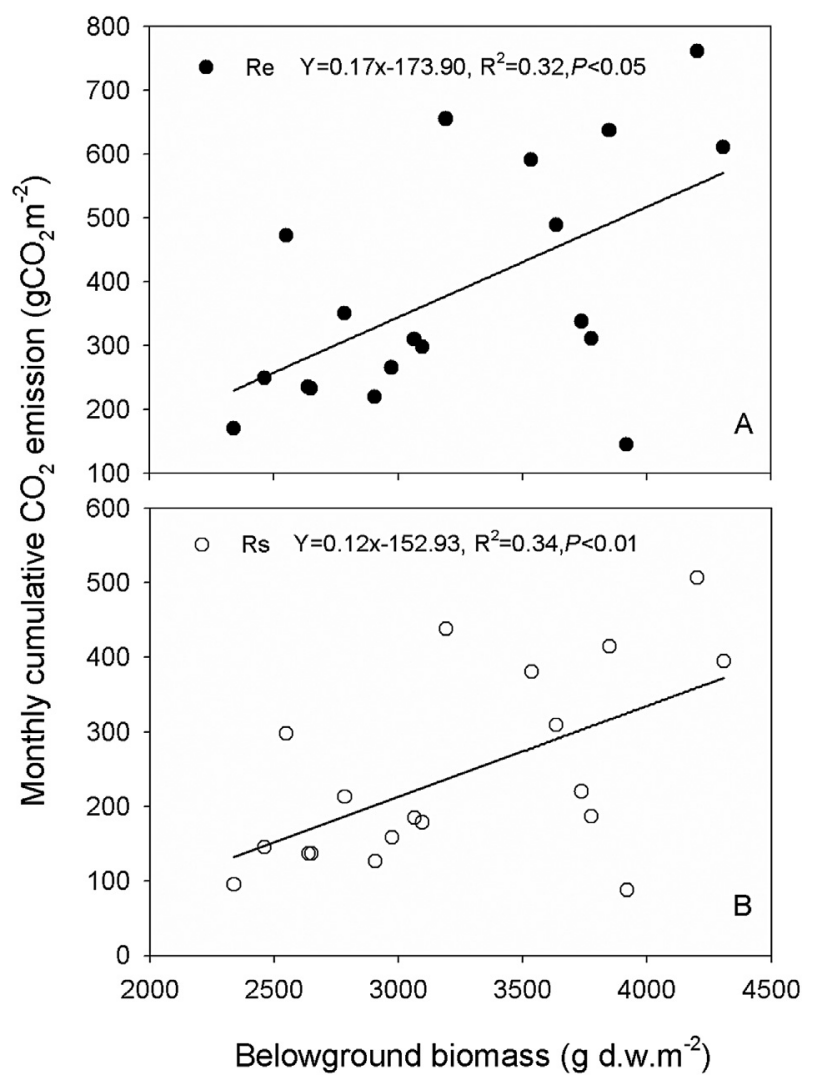

Fig. 5. Effects of belowground biomass on monthly cumulative $\mathrm{CO}_{2}$ emission from treatment of Re (A) and Rs (B). 
higher $Q_{10}$ values derived from soil temperature than air temperature (Fig. 4B). There was no significant correlation between soil moisture and $\mathrm{CO}_{2}$ flux rates from the three treatments (Fig. $4 \mathrm{C}$ ).

The cumulative monthly $\mathrm{CO}_{2}$ emission from the Re treatment was significantly positively related to monthly belowground biomass, but not to aboveground and total biomass. Changes in monthly belowground biomass could explain $32 \%$ of the variation in $\mathrm{CO}_{2}$ flux from the Re treatment (Fig. 5A). The similar positive relation was observed between monthly belowground biomass and $\mathrm{CO}_{2}$ fluxes from the Rs treatment, which could explain $34 \%$ of $\mathrm{CO}_{2}$ flux variability (Fig. 5B).

\section{Discussions}

\subsection{Ecosystem respiration and its components}

Because of large plant biomass and no obvious standing water on the soil surface, as well as optimal temperature, ecosystem respiration from our site (i.e. $98.01-1359.25 \mathrm{mg} \mathrm{CO}_{2} \mathrm{~m}^{-2} \mathrm{~h}^{-1}$ ) was much higher than most other littoral zones of lakes. For example, the summertime ecosystem respiration varied from 20.68 to $127.6 \mathrm{mg} \mathrm{CO}_{2} \mathrm{~m}^{-2} \mathrm{~h}^{-1}$ from the littoral zone of Lake Daming, East Antarctica (Ding et al., 2013), 102.5 to $166.8 \mathrm{mg} \mathrm{CO}_{2} \mathrm{~m}^{-2} \mathrm{~h}^{-1}$ from the littoral zone of an alpine lake on the Tibetan plateau (Hirota et al., 2006), and $14-725 \mathrm{mg} \mathrm{CO} \mathrm{m}^{-2} \mathrm{~h}^{-1}$ from Japanese fringing zones of Lake Nakaumi (Hirota et al., 2007). However, by comparison, the littoral zone of boreal Lake Kevätön showed a substantial variation of $\mathrm{CO}_{2}$ release ranging from 110 to $2340 \mathrm{mg} \mathrm{CO}_{2} \mathrm{~m}^{-2} \mathrm{~h}^{-1}$ for laboratory incubation and 4 to $2800 \mathrm{mg} \mathrm{CO}_{2} \mathrm{~m}^{-2} \mathrm{~h}^{-1}$ for in situ measurement, respectively (Liikanen et al., 2003; Larmola et al., 2003).

Separating soil microbial respiration was central for ecosystem components partition. There are several methods for this heterotrophic respiration partitioning (Hanson et al., 2000; Kuzyakov, 2006). Kuzyakov (2006) suggested that the method with the lowest disturbance and the highest universality was the regression technique, which was further modified by other studies (Zhang et al., 2009; Bao et al., 2010). However, the regression technique is not applicable to our sites, because it is impossible to find biomass gradients for flux measurements, as the coverage of Carex is over $95 \%$, with substantial uniformity. In contrast, by cutting off old plant roots and preventing new roots encroachment, Zhou et al. (2007) found $\mathrm{CO}_{2}$ efflux could represent soil microbial respiration after 5 months. Based on this method, we found $\mathrm{CO}_{2}$ efflux from the Rh treatment could be treated as soil microbial respiration after about 9 months in our site. Combined with the Re and Rs treatments, we partitioned ecosystem respiration (Re) into autotrophic

Table 2

Ratios of various components to ecosystem respiration and their temperature sensitivities.

\begin{tabular}{|c|c|c|c|c|c|c|}
\hline \multirow[t]{2}{*}{ Respiration } & \multirow{2}{*}{$\begin{array}{l}\text { Ratio of various } \\
\text { components to Re }\end{array}$} & \multicolumn{4}{|c|}{$R=a e^{b t}$} & \multirow[t]{2}{*}{$Q_{10}$} \\
\hline & & $\bar{a}$ & $b$ & $R^{2}$ & $P$ & \\
\hline $\begin{array}{l}\text { Ecosystem } \\
\text { respiration }\end{array}$ & 1.00 & 174.99 & 0.072 & 0.74 & $<0.001$ & 2.05 \\
\hline Plant respiration & $0.62 \pm 0.11$ & 97.81 & 0.0812 & 0.67 & $<0.001$ & 2.25 \\
\hline Root respiration & $0.26 \pm 0.06$ & 50.72 & 0.0671 & 0.53 & $<0.001$ & 1.96 \\
\hline Shoot respiration & $0.36 \pm 0.10$ & 47.65 & 0.0922 & 0.65 & $<0.001$ & 2.51 \\
\hline $\begin{array}{l}\text { Total soil } \\
\text { respiration }\end{array}$ & $0.64 \pm 0.10$ & 130.52 & 0.0602 & 0.71 & $<0.001$ & 1.83 \\
\hline $\begin{array}{l}\text { Soil microbial } \\
\text { respiration }\end{array}$ & $0.38 \pm 0.12$ & 80.92 & 0.0545 & 0.72 & $<0.001$ & 1.72 \\
\hline
\end{tabular}

$R$ is mean $\mathrm{CO}_{2}$ flux rate, $t$ is flux time air temperature, $a$ is the intercept of $\mathrm{CO}_{2}$ flux when air temperature is zero, and $b$ represents the temperature sensitivity of $\mathrm{CO}_{2}$ flux, $Q_{10}=\exp (10 b)$. plant respiration (Rp) and heterotrophic microbial respiration ( $R \mathrm{~h}$ ). Moreover, plant respiration was further separated into shoot respiration (Rsh) and root respiration ( $\mathrm{Rr})$. Shoot and root respiration accounted for $36 \%$ and $26 \%$ of Re, respectively, whereas Rh was responsible for $38 \%$ of Re. In addition, the ratio of total soil respiration (Rs) to ecosystem respiration was 0.64 (Table 2 ). To date, the ecosystem respiration components partition was mostly conducted in forests and grasslands (Janssens et al., 2001; Davidson et al., 2006; Zhang et al., 2009). The total soil respiration typically contributes $30-80 \%$ of annual ecosystem respiration in forests (Davidson et al., 2006). The Rs to Re ratio in grasslands varied from 0.4 to 1 in a tallgrass prairie (Franzluebbers et al., 2002), and 0.43 to 0.56 in a Tibetan alpine meadow (Zhang et al., 2009). Our estimations in this littoral meadow are within the range observed in
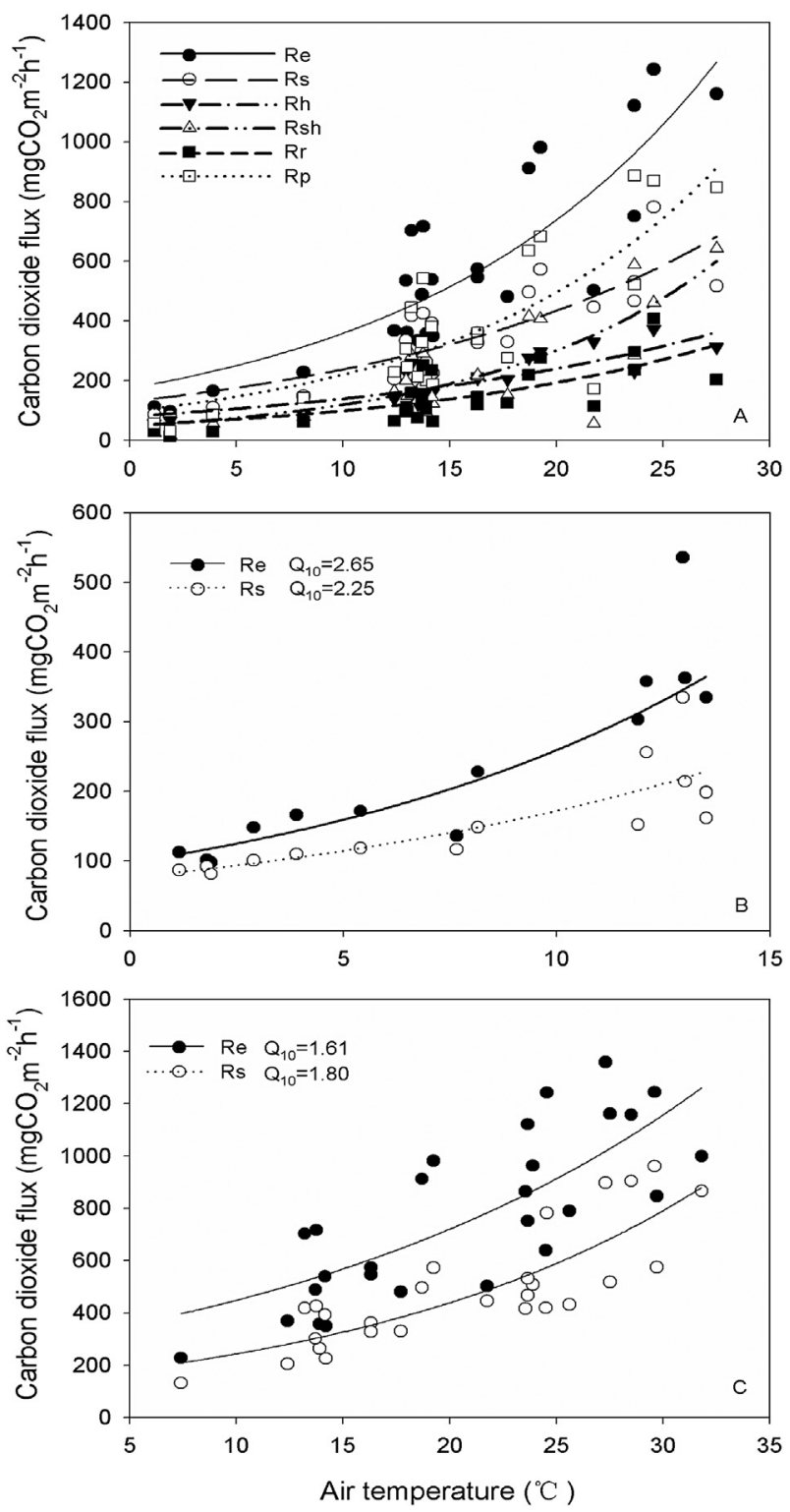

Fig. 6. Dependency of various ecosystem respiration components on air temperature during the period from March 2010 to June 2011(A). The equations for predicting $\mathrm{CO}_{2}$ flux from air temperature were shown in Table 2. Re, Rs, Rh, Rsh, Rr and Rp were the abbreviation of Ecosystem respiration, total soil respiration, heterotrophic soil microbial respiration, shoot respiration, root respiration and plant respiration, respectively. Temperature sensitivity of ecosystem respiration (Re) and total soil respiration (Rs) differed in winter time (B) and non-winter time (C). 
forests and tallgrass prairie. The low Rs/Re ratios in alpine meadows were mainly ascribed to observations over the short-term growing seasons (Zhang et al., 2009). Additionally, the Rs/Re ratio in this study showed clear seasonal pattern, with the maximum in plant dormant periods and the minimum at peaks of growing periods. The Rs/Re ratio was not related to soil respiration, but significantly negatively correlated with the ecosystem respiration $(r=-0.33$, $P<0.05, n=41$ ), which implied the differences in the phenology of growth of aboveground and belowground plant tissues, mobilization and use of stored substrates (Davidson et al., 2006).

Numerous studies have attempted to partition the total soil respiration into root and microbial respiration. The contribution of root respiration to total soil respiration varied from $10 \%$ to $90 \%$ depending on vegetation type and season of the year (Hanson et al., 2000). However, the large variability within or between ecosystems may also partly due to the different methods adopted for partitioning the respiration components. For example, in the same Inner Mongolia desert steppe site, Bao et al. (2010) found the contribution of root respiration to total soil respiration ranged from $32 \%$ to $81 \%$ (mean $55 \%$ ) estimated by exponential regression, but from $14 \%$ to $69 \%$ (mean $46 \%$ ) estimated by linear regression. Root respiration at this site accounted for $18 \%-60 \%$ (mean $41 \%$ ) of total soil respiration, which fell well in the range reported for grasslands (range from 6\% to 81\%) (Gupta and Singh, 1981; Yazaki et al., 2004; Jia et al., 2006; Wang et al., 2006a,b; Zhou et al., 2007; Bao et al., 2010).

\subsection{Temperature sensitivity and its variation}

Ecosystem respiration components in this study largely differed in temperature sensitivity. The $Q_{10}$ values ranged from 1.7 to 2.5 , with the maximum for shoot respiration and the minimum for microbial respiration (Fig. 6A) (Table 2). The overall $Q_{10}$ values for ecosystem respiration components were within the range between 1.3 and 3.3 found in other ecosystems (Raich and Schlesinger, 1992; Tjoelker et al., 2001). Temperature sensitivity of autotrophic and heterotrophic respiration differed in some previous studies (Boone et al., 1998; Pregitzer et al., 2000; Epron et al., 2001), but not in others (Bhupinderpal-Singh et al., 2003; Irvine et al., 2005; Sulzman et al., 2005). In this study, we found both autotrophic shoot and root respiration had higher $Q_{10}$ values than heterotrophic soil microbial respiration. Probably, plants have more respiratory substrate availability than soil microorganisms. As described by the Michaelis-Menten kinetics equation, the low substrate availability generally results in low $Q_{10}$ values (Davidson and Janssens, 2006).

We divided our Re and Rs flux data into two groups: winter fluxes from December to February and non-winter flux at other time, respectively. Subsequently, we found both $\mathrm{Re}$ and Rs demonstrated higher $Q_{10}$ values in winter periods than non-winter periods (Fig. 6B, C), suggesting Re and Rs are more sensitive to increasing temperature in cold periods than in warmer periods. For Poyang lake meadows, winter periods generally corresponded to the driest soil regime (Hu et al., 2010). Given the higher $Q_{10}$ values and aerobic decomposition, winter periods may have substantial $\mathrm{CO}_{2}$ emissions under climate warming conditions. The temperature sensitivity of respiratory processes in ecosystems is a key parameter in modeling climate-carbon cycle feedback (Davidson and Janssens, 2006). Most models generally treated the temperature sensitivity as a constant (Zhou et al., 2009a). Here our results indicated ecosystem respiration components should be taken into consideration separately when using the $Q_{10}$ function to predict the response of wetland respiratory processes to global warming.

Recently, extensive debates have been done on temperature sensitivity focusing on the soil organic carbon quality, in which the temperature sensitivity of recalcitrant organic carbon was greater than (Conant et al., 2008a, b; Craine et al., 2010), equivalent to (Fang et al., 2005; Conen et al., 2006), or less than (Liski et al., 1999; Rey and Jarvis, 2006) that of labile organic carbon. However, most of the conclusions were drawn from soil incubation experiments from well-drained upland ecosystems and with less attention to wetland soils (Davidson and Janssens, 2006). In this study, since the onset of clipping aboveground shoots and cutting off belowground old roots, the Rh treatment plots lacked an input of above-ground photosynthates and litters. Consequently, the labile carbon was gradually depleted and left more recalcitrant with timing. Therefore, we compared temperature sensitivity of Rh measured between March to December in 2010 and January to June in 2011 (Fig. 7A). The $Q_{10}$ value was 2.69 in the previous period, but 1.57 for the latter period. Since the two flux measurements periods had similar mean air temperature ( 16.5 and $16.7{ }^{\circ} \mathrm{C}$ ), the results may provide a field observation in supporting that more labile organic carbon had higher apparent temperature sensitivity in wetland soils.

Soil moisture is an important environmental variable in regulating respiratory processes, but the relation between respiratory temperature sensitivity and moisture has not been adequately quantified. Several previous studies suggested that Rs became more sensitive to temperature in response to rising soil moisture (Janssens and Pilegaard, 2003; Craine and Gelderman, 2011). In this study, to explore effect of soil moisture on temperature sensitivity, we divided our flux data into two groups: higher than mean soil moisture (55\%) and lower than mean soil moisture. Irrespective of individual treatments, we found similar $Q_{10}$ values for the two
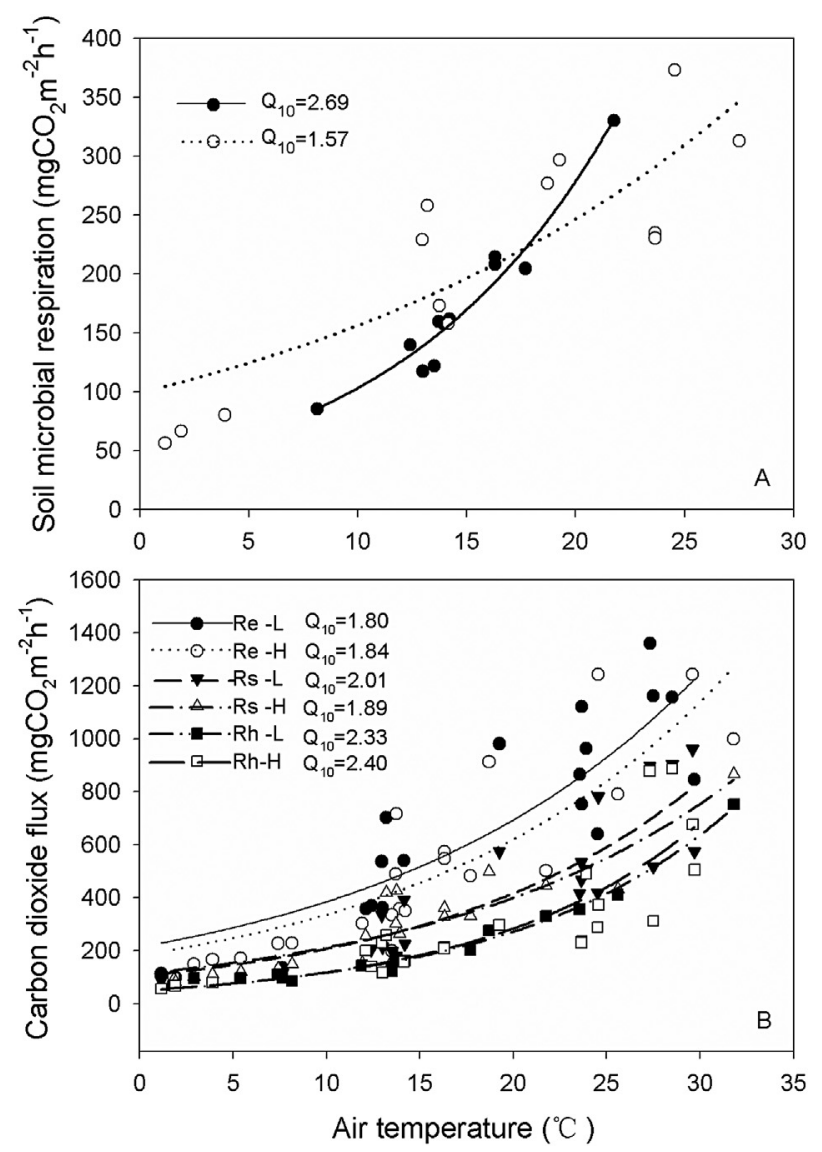

Fig. 7. The temperature sensitivity of soil microbial decomposition of relative more labile organic carbon during March to December in 2010 (Solid circle), and relative more recalcitrant organic carbon during January to June in 2011 (Empty circle) (A). The temperature sensitivity of $\mathrm{CO}_{2}$ flux measured at low and high soil moisture (B), $\mathrm{L}$ and $\mathrm{H}$ indicated soil moisture was lower or higher than $55 \%$. 
subgroups, suggesting no soil moisture effect on respiratory temperature sensitivity in our sites (Fig. 7B). This may be mainly due to the relatively high soil moisture with low variations in this wetland soil, as neither $\mathrm{CO}_{2}$ fluxes from the three treatments was related to soil moisture.

\subsection{Carbon balance during the drawdown period}

Net $C$ exchange of a wetland ecosystem is the difference between $C$ uptake through NPP and C loss through heterotrophic respiration and methane emissions. According to our previous study, methane emission during drawdown period was nearly ignorable in contrast to $\mathrm{CO}_{2}$ (Hu et al., 2011a, b). Therefore we estimated net ecosystem carbon exchange as the difference between NPP and carbon loss through soil heterotrophic respiration in two continuous drawdown periods, which lasted from September 6, 2009 to April 14, 2010 and October 2, 2010 to June 16, 2011, respectively. The littoral Carex meadow acted as significant carbon sink in both drawdown periods (Table 3).

Previous study had suggested littoral zone acted as a carbon sink or source largely depending on water level regime and vegetation coverage (Larmola et al., 2003). For example, in the littoral zone of boreal lake during open water period, Larmola et al. (2003) found the lower flooded zone had a net $\mathrm{CO}_{2}$ uptake of $21.6-74.4 \mathrm{~g} \mathrm{C} \mathrm{m}^{-2}$, but the upper flooded zone had a net $\mathrm{CO}_{2}$ loss of $13.2-85.2 \mathrm{~g} \mathrm{C} \mathrm{m}^{-2}$. Similarly, the mean net $\mathrm{CO}_{2}$ uptake was 70.8 and $36.9 \mathrm{mg} \mathrm{CO}_{2}$ $\mathrm{m}^{-2} \mathrm{~h}^{-1}$ in the littoral zone of Lake Mochou and Tuanjie, East Antarctica, respectively (Zhu et al., 2010), but a weak sink even source of $\mathrm{CO}_{2}$ for the littoral zone of Lake Daming, East Antarctica (Ding et al., 2013). In the littoral zone of Lake Nakaumi, Japan, an uptake $\mathrm{CO}_{2}$ flux of $23-320 \mathrm{mg} \mathrm{CO} \mathrm{Cm}^{-2} \mathrm{~h}^{-1}$ was reported in the salt marsh, but a $\mathrm{CO}_{2}$ release of $14-75 \mathrm{mg} \mathrm{CO}_{2} \mathrm{~m}^{-2} \mathrm{~h}^{-1}$ in the sandy shore (Hirota et al., 2007). Additionally, in the littoral zone of a tropical savanna reservoir, net carbon dioxide release varied with water level from 2.46 to $50.96 \mathrm{mg} \mathrm{CO}_{2} \mathrm{~m}^{-2} \mathrm{~h}^{-1}$ (Bergier et al., 2011). By contrast, annual double growing seasons made the littoral Carex meadow of Poyang Lake have much stronger carbon sequestration than above-mentioned littoral wetlands and many other wetland types across the world (Bridgham et al., 2006; Zhao et al., 2010; Song et al., 2011; Mitsch et al., 2012).

However, there was large intra- and inter-drawdown period variations of carbon sink intensity. For example, both drawdown periods have much stronger carbon sequestration in spring growing season than autumn growing season after summer flood. At our site, the summer flood only lasted 67 days from July 1 to September 6 in 2009, but 171 days from April 14 to October 2 in 2010. The long flood duration in 2010 substantially altered the Carex growth, particularly aboveground NPP (ANPP) in the following drawdown period. For instance, autumn ANPP in 2010 accounted for $46.6 \%$ of that in 2009. Likewise, spring ANNP in 2011

Table 3

Carbon balance of Carex meadow during drawdown periods.

\begin{tabular}{llclll}
\hline $\begin{array}{l}\text { Carbon budget } \\
\left(\mathrm{g} \mathrm{C} \mathrm{m}^{-2}\right)\end{array}$ & \multicolumn{2}{l}{ 2009-2010 drawdown period } & $\begin{array}{l}\text { 2010-2011 drawdown } \\
\text { period }\end{array}$ \\
\cline { 2 - 3 } \cline { 5 - 6 } & $\begin{array}{l}\text { September to } \\
\text { January }\end{array}$ & $\begin{array}{l}\text { February to } \\
\text { April }\end{array}$ & $\begin{array}{l}\text { October to } \\
\text { January }\end{array}$ & $\begin{array}{l}\text { February to } \\
\text { June }\end{array}$ \\
\hline Rh & $199.4 \pm 16.2$ & $74.9 \pm 5.4$ & $128.1 \pm 9.3$ & $199.5 \pm 16.6$ \\
ANPP & $361.9 \pm 46.3$ & $750.3 \pm 73.7$ & $168.5 \pm 20.5$ & $464.8 \pm 79.0$ \\
BNPP & $145.5 \pm 101.0$ & $401.7 \pm 120.7$ & $100.0 \pm 88.6$ & $510.6 \pm 155.4$ \\
TNPP & $507.4 \pm 147.3$ & $1152.0 \pm 194.4$ & $268.5 \pm 109.1$ & $975.4 \pm 234.4$ \\
TNPP-Rh & $308.0 \pm 131.4$ & $1077.1 \pm 189.5$ & $140.4 \pm 101.1$ & $775.9 \pm 217.9$ \\
\hline
\end{tabular}

$\mathrm{Rh}$ indicated heterotrophic respiration. ANPP, BNPP and TNPP represented aboveground, belowground and total net primary productivity, respectively. Data represent the mean \pm standard deviation. decreased by $38.1 \%$ in contrast to 2010 . As a result, carbon sequestration largely differed in the two drawdown periods. Considering over $938 \mathrm{~km}^{2}$, approximately $30 \%$ of the total lake area, the littoral zone would contribute substantially to the whole lake carbon balance. According to the long-term hydrologic record, the drawdown durations for most of the littoral areas varied from 165 to 271 days (Liu et al., 2006). Therefore, based on the heterotrophic respiration rate in this study and annual NPP calculated by Zhou et al. (2009b), we estimated the total annual carbon sink of the littoral areas during drawdown periods as a range of

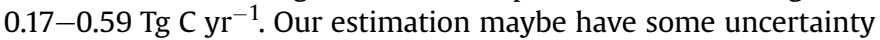
due to the spatial variation of Rh. Given Rh derived from more aerobic meadow site and decreased with the increase of anaerobic condition, the total carbon sink may be underestimated.

\section{Conclusion}

The temporal variations of ecosystem respiration and its components in the littoral meadow of Poyang Lake were mainly controlled by temperature, rather than soil moisture. Shoot, root and soil microbial respiration contributed approximately $36 \%, 26 \%$ and $38 \%$ to the ecosystem respiration, respectively. Their $Q_{10}$ values ranged from 1.72 to 2.51 , with the maximum for shoot respiration and the minimum for microbial respiration. These $Q_{10}$ values varied widely with time and among ecosystem respiratory components and hence could not be treated as a constant. The littoral Carex meadow acted as strong carbon sink during drawdown period, however, the previous summer flood duration could substantially alter carbon sink intensity in the following drawdown period.

\section{Acknowledgment}

This study was supported by National Natural Science Foundation of China (Grant No. 31270522 and 40803022) and the Collaborative Innovation Center for Major Ecological Security Issues of Jiangxi Province and Monitoring Implementation (No.JXS-EW-00).

\section{References}

Bao, F., Zhou, G.S., Wang, F.Y., Sui, X.H., 2010. Partitioning soil respiration in a temperate desert steppe in inner Mongolia using exponential regression method. Soil Biol. Biochem. 42, 2339-2341.

Bergier, I., Novo, E.M., Ramos, F.M., Mazzi, E.A., Rasera, M.F., 2011. Carbon dioxide and methane fluxes in the littoral zone of a tropical Savanna reservoir (Corumba, Brazil). Oecologia Aust. 15 (3), 666-681.

Bernal, B., Mitsch, W.J., 2012. Comparing carbon sequestration in temperate freshwater wetland communities. Glob. Change Biol. 18, 1636-1647.

Bhupinderpal-Singh, Nordgren, A. Ottosson Löfvenius, M. Högberg M.N. Mellander, P.E., Högberg, P., 2003. Tree root and soil heterotrophic respiration as revealed by girdling of boreal Scots pine forest: extending observations beyond the first year. Plant Cell Environ. 26 (8), 1287-1296.

Boone, R.D., Nadelhoffer, K.J., Canary, J.D., Kaye, J.P., 1998. Roots exert a strong influence on the temperature sensitivity of soil respiration. Nature 396, 570-572.

Bridgham, S.D., Megonigal, J.P., Keller, J.K., Bliss, N.B., Trettin, C., 2006. The carbon balance of North American wetlands. Wetlands 26, 889-916.

Chen, H., Wu, N., Yao, S.P., Gao, Y.H., Zhu, D., Wang, Y.F., Xiong, W., Yuan, X., 2009. High methane emissions from a littoral zone on the Qinghai-Tibetan plateau. Atmos. Environ. 43, 4995-5000.

Conant, R.T., Drijber, R.A., Haddix, M.L., Parton, W.J., Paul, E.A., Plante, A.F., Six, J. Megansteinweg, J., 2008a. Sensitivity of organic matter decomposition to warming varies with its quality. Glob. Change Biol. 14, 868-877.

Conant, R.T., Steinweg, J.M., Haddix, M.L., Paul, E.A., Plante, A.F., Six, J., 2008b. Experimental warming shows that decomposition temperature sensitivity increases with soil organic matter recalcitrance. Ecology 89, 2384-2391.

Conen, F., Leifeld, J., Seth, B., Alewell, C., 2006. Warming mineralizes young and old soil carbon equally. Biogeosciences 3, 515-519.

Craine, J.M., Fierer, N., McLauchlan, K.K., 2010. Widespread coupling between the rate and temperature sensitivity of organic matter decay. Nat. Geosci. 3, 854-857.

Craine, J.M., Gelderman, T.M., 2011. Soil moisture controls on temperature sensitivity of soil organic carbon decomposition for a mesic grassland. Soil Biol. Biochem. 43, 455-457. 
Davidson, E.A., Janssens, I.A., 2006. Temperature sensitivity of soil carbon decomposition and feedbacks to climate change. Nature 440, 165-173.

Davidson, E.A., Richardson, A.D., Savage, K.E., Hollinger, D.Y., 2006. A distinct seasonal pattern of the ratio of soil respiration to total ecosystem respiration in a spruce-dominated forest. Glob. Change Biol. 12, 230-239.

Ding, W.X., Cai, Z.C., Tsuruta, H., 2005. Plant species effects on methane emissions from freshwater marshes. Atmos. Environ. 39, 3199-3207.

Ding, W., Zhu, R., Ma, D., Xu, H., 2013. Summertime fluxes of $\mathrm{N}_{2} \mathrm{O}, \mathrm{CH}_{4}$ and $\mathrm{CO}_{2}$ from the littoral zone of Lake Daming, East Antarctica: effects of environmental conditions. Antarct. Sci. 25 (06), 752-762.

Epron, D., Le Dantec, V., Dufrene, E., Granier, A., 2001. Seasonal dynamics of soil carbon dioxide efflux and simulated rhizosphere respiration in a beech forest. Tree Physiol. 21, 145-152.

Fan, Z., David McGuire, A., Turetsky, M.R., Harden, J.W., Michael Waddington, J., Kane, E.S., 2013. The response of soil organic carbon of a rich fen peatland in interior Alaska to projected climate change. Glob. change Biol. 19 (2), 604-620.

Fang, C.M., Smith, P., Moncrieff, J.B., Smith, J.U., 2005. Similar response of labile and resistant soil organic matter pools to changes in temperature. Nature 433, 57-59.

Franzluebbers, K., Franzluevvers, A.J., Jawson, M.D., 2002. Environmental controls on soil and whole-ecosystem respiration from a tallgrass prairie. Soil Sci. Soc. Am. J. 66, 254-262.

Gorham, E., 1991. Northern peatlands: role in the carbon cycle and probable responses to climatic warming. Ecol. Appl. 1, 182-195.

Gupta, S.R., Singh, J.S., 1981. Soil respiration in a tropical grassland. Soil Biol. Biochem. 13 (4), 261-268.

Hanson, P.J., Edwards, N.T., Garten, C.T., Andrews, J.A., 2000. Separating root and soil microbial contributions to soil respiration:a review of methods and observations. Biogeochemistry 48, 115-146.

Hirota, M., Tang, Y., Hu, Q., Hirata, S., Kato, T., Mo, W., Cao, G., Mariko, S., 2006. Carbon dioxide dynamics and controls in a deepwater wetland on the QinghaiTibetan Plateau. Ecosystems 9, 673-688.

Hirota, M., Senga, Y., Seike, Y., Nohara, S., Kunii, H., 2007. Fluxes of carbon dioxide, methane and nitrous oxide in two contrastive fringing zones of coastal lagoon, Lake Nakaumi, Japan. Chemosphere 68 (3), 597-603.

Hu, Z.P., Ge, G., Liu, C., Chen, F.S., Li, S., 2010. Structure of Poyang Lake wetland plants ecosystem and influence of lake water level for the structure. Resour. Environ. Yangtze Basin 19 (6), 597-605 (in Chinese).

Hu, Q.W., Zhu, L.L., Xing, R.X., Yao, B., Hu, B.H., 2011a. Methane emission from a Carex-dominated wetland in Poyang Lake. Acta Ecol. Sin. 31 (17), 4851-4857 (in Chinese).

Hu, Q.W., Xing, R.X., Zhu, L.L., Wu, Q., Yao, B., Liu, Y., Hu, B.H., 2011b. Characteristics of $\mathrm{CO}_{2}$ emission from Carex-dominated wetland in Poyang Lake during nonflooded period. Chin. J. Appl. Ecol. 22 (6), 1431-1436 (in Chinese).

Irvine, J., Law, B.E., Kurpius, M.R., 2005. Coupling of canopy gas exchange with root and rhizosphere respiration in a semi-arid forest. Biogeochemistry 73, 271-282.

Janssens, I.A., Pilegaard, K.I.M., 2003. Large seasonal changes in $\mathrm{Q}_{10}$ of soil respiration in a beech forest. Glob. Change Biol. 9 (6), 911-918.

Janssens, I.A., Lankreijer, H., Matteucci, G., Kowalski,, A.S., Buchmann, N., Epron, D., Pilegaard, K., Kutsch, W., Longdoz, B., Grünwald, T., Montagnani, L., Dore, S. Rebmann, C., Moors, E.J., Grelle, A., Rannik, ü., Morgenstern, K., Oltchev, S. Clement, R., Guemundsson, J., Minerbi, S., Berbigier, P., Ibrom, A., Moncrieff, J., Aubinet, M., Bernhofer, C., Jensen, N.O., Vesala, T., Granier, A., Schulze, E.-D., Lindroth, A., Dolman, A.J., Jarvis, P.G., Ceulemans, R., Valentini, R., 2001. Productivity overshadows temperature in determining soil and ecosystem respiration across European forests. Glob. Change Biol. 7, 269-278.

Jia, B.R., Zhou, G.S., Wang, F.Y., Wang, Y.H., Yuan, W.P., Zhou, L., 2006. Partitioning root and microbial contribution to soil respiration in Leymus chinensis populations. Soil Biol. Biochem. 38, 653-660.

Kuzyakov, Y., 2006. Sources of $\mathrm{CO}_{2}$ efflux from soil and review of partitioning methods. Soil Biol. Biochem. 38 (3), 425-448.

Larmola, T., Alm, J., Juutinen, S., Martikainen, P.J., Silvola, J., 2003. Ecosystem $\mathrm{CO}_{2}$ exchange and plant biomass in the littoral zone of a boreal eutrophic lake. Freshw. Biol. 48, 1295-1310.

Liikanen, A., Ratilainen, E., Saarnio, S., Alm, J., Martikainen, P.J., Silvola, J., 2003. Greenhouse gas dynamics in boreal, littoral sediments under raised $\mathrm{CO}_{2}$ and nitrogen supply. Freshwat. Biol. 48 (3), 500-511.

Liski, J., Ilvesniemi, H., Makela, A., Westman, C.J., 1999. CO 2 emissions from soil in response to climatic warming are overestimated -the decomposition of old soil organic matter is tolerant of temperature. Ambio 28, 171-174.

Liu, X.Z., Fan, S.B., Hu, B.H., 2006. Comprehensive and Scientific Survey of Jiangxi Nanjishan Wetland Nature Reserve. Chinese Forestry Press, Beijing (in Chinese).

Lund, M., Lafleur, P.M., Roulet, N.T., Lindroth, A., Christensen, T.R., Aurela, M., Chojnicki, B.H., Flanagan, L.B., Humphreys, E.R., Laurila, T., Oechel, W.C., Olejnik, J., Rinne, J., Schubert, P., Nilsson, M.B., 2010. Variability in exchange of $\mathrm{CO}_{2}$ across 12 northern peatland and tundra sites. Glob. Change Biol. 16, 2436-2448. http://dx.doi.org/10.1111/j.1365-2486.2009.02104.x.

Mitsch, W.J., Gosselink, J.G., 2007. Wetlands, fourth ed. Wiley, Hoboken.

Mitsch, W.J., Nahlik, A.M., Wolski, P., Bernal, B., Zhang, L., Ramberg, L., 2010. Tropical wetlands: seasonal hydrologic pulsing, carbon sequestration, and methane emissions. Wetlands Ecol. Manag. 18, 573-586.

Mitsch, W.J., Bernal, B., Nahlik, A.M., Mander, Ü., Zhang, L., Anderson, C.J., Jørgensen, S.E., Brix, H., 2012. Wetlands, carbon, and climate change. Landsc. Ecol. 28, 583-597.
Pregitzer, K.S., King, J.S., Burton, A.J., Brown, S.E., 2000. Responses of tree fine roots to temperature. New. Phytol. 147, 105-115.

Raich, J.W., Schlesinger, W.H., 1992. The global carbon dioxide flux in soil respiration and its relationship to vegetation and climate. Tellus 44B, 81-99.

Rey, A., Jarvis, P., 2006. Modelling the effect of temperature on carbon mineralization rates across a network of European forest sites (FORCAST). Glob. Change Biol. 12, 1894-1908.

Rey, A., Pegoraro, E., Tedeschi, V., De Parri, I., Jarvis, P.G., Valentini, R., 2002. Annual variation in soil respiration and its components in a coppice oak forest in Central Italy. Glob. Change Biol. 8, 851-866.

Roulet, N.T., 2000. Peatlands, carbon storage, greenhouse gases, and the Kyoto protocol: prospects and significance for Canada. Wetlands 20, 605-615.

Roulet, N.T., Lafleur, P.M., Richard, P.J.H., Moore, T.R., Humphreys, E.R., Bubier, J., 2007. Contemporary carbon balance and late Holocene carbon accumulation in a northern peatland. Glob. Change Biol. 13, 397-411.

Shi, X.Z., Yu, D.S., Sun, W.X., Wang, H.J., Zhao, Q.G., Gong, Z.T., 2004. Reference benchmarks relating to great groups of genetic soil classification of China with soil taxonomy. Chin. Sci. Bull. 49 (14), 1507-1511.

Song, C.C., Sun, L., Huang, Y., Wang, Y.S., Wan, Z.M., 2011. Carbon exchange in a freshwater marsh in the Sanjiang plain, northeastern China. Agric. For. Meteorol. 151 (8), 1131-1138.

Sulzman, E.W., Brant, J.B., Bowden, R.D., Lajtha, K., 2005. Contribution of aboveground litter, belowground litter, and rhizosphere respiration to total soil $\mathrm{CO}_{2}$ efflux in an old growth coniferous forest. Biogeochemistry 73, 231-256.

They, N.H., da Motta Marques, D., Souza, R.S., 2013. Lower respiration in the littoral zone of a subtropical shallow lake. Front. Microbiol. 3. http://dx.doi.org 10.3389/fmicb.2012.00434.

Tjoelker, M.G., Oleksyn, J., Reich, P.B., 2001. Modelling respiration of vegetation: evidence for a general temperature-dependent $\mathrm{Q}_{10}$. Glob. Change Biol. 7 223-230.

Valentini, R., Matteucci, G., Dolman, A.J., Schulze, E.D., Rebmann, C., Moors, E.J. Granier, A., Gross, P., Jensen, N.O., Pilegaard, K., Lindroth, A., Grelle, A. Bernhofer, C., Grünwald, T., Aubinet, M., Ceulemans, R., Kowalski, A.S., Vesala, T. Rannik, Ü. Berbigier, P. Loustau, D. Gumundsson, J. Thorgeirsson, H. Ibrom, A Morgenstern, K., Clement, R., Moncrieff, J., Montagnani, L., Minerbi, S. Jarvis, P.G., 2000. Respiration as the main determinant of carbon balance in European forests. Nature 404, 861-865.

Wang, Y.S., Wang, Y.H., 2003. Quick measurement of $\mathrm{CH}_{4}, \mathrm{CO}_{2}$ and $\mathrm{N}_{2} \mathrm{O}$ emissions from short-plant ecosystems. Adv. Atmos. Sci. 20, 842-844.

Wang, W., Guo, J.X., Feng, J., Oikawa, T., 2006a. Contribution of root respiration to total soil respiration in a Leymus chinensis (trin.) tzvel, grassland of Northeast China. J. Integr. Plant Biol. 48 (4), 409-414.

Wang, W., Jiang, F., Oikawa, T., 2006b. Contribution of root and microbial respiration to soil $\mathrm{CO}_{2}$ efflux and their environmental controls in a humid temperate grassland of Japan. Pedosphere 19 (1), 31-39.

Wang, J.B., Zhu, T.C., Ni, H.W., Zhong, H.X., Fu, X.L., Wang, J.F., 2013. Effects of elevated $\mathrm{CO}_{2}$ and nitrogen deposition on ecosystem carbon fluxes on the sanjiang Plain wetland in Northeast China. PLoS One 8 (6), e66563. http:// dx.doi.org/10.1371/journal.pone.0066563.

Xu, X.F., Tian, H.Q., 2012. Methane exchange between marshland and the atmosphere over China during 1949-2008. Glob. Biogeochem. Cycles 26, GB2006. http://dx.doi.org/10.1029/2010GB003946.

Yang, M., Geng, X., Grace, J., Lu, C., Zhu, Y., Zhou, Y., Lei, G.C., 2014. Spatial and seasonal $\mathrm{CH}_{4}$ flux in the littoral zone of Miyun reservoir near Beijing: the effects of water level and its fluctuation. PloS One 9 (4), e94275.

Yazaki, Y., Mariko, S., Koizumi, H., 2004. Carbon dynamics and budget in a Mis canthus sinensis grassland in Japan. Ecol. Res. 19 (5), 511-520.

Yu, G.R., Zhu, X.J., Fu, Y.L., He, H.L., Wang, Q.F., Wen, X.F., Li, X.R., Zhang, L.M., Zhang, L., Su, W., Li, S.G., Sun, X.M., Zhang, Y.P., Zhang, J.H., Yan, J.H., Wang, H.M., Zhou, G.S., Jia, B.R., Xiang, W.H., Li, Y.N., Zhao, L., Wang, Y.F., Shi, P.L., Chen, S.P., Xin, X.P., Zhao, F.H., Wang, Y.Y., Tong, C.L., 2013. Spatial patterns and climate drivers of carbon fluxes in terrestrial ecosystems of China. Glob. Change Biol. 19, 798-810. http://dx.doi.org/10.1111/gcb.12079.

Zhang, P.C., Tang, Y.H., Hirota, M., Yamamoto, A., Mariko, S., 2009. Using of a regression method to partition sources of ecosystem respiration in an alpine meadow. Soil Biol. Biochem. 41 (4), 663-670.

Zhang, Q., Li, L., Wang, Y.G., Werner, A.D., Xin, P., Jiang, T., Barry, D.A., 2012. Has the three-gorges dam made the Poyang lake wetlands wetter and drier? Geophys. Res. Lett. 39 (20) http://dx.doi.org/10.1029/2012GL053431.

Zhao, L., Li, J., Xu, S.X., Zhou, H.K., Li, Y.N., Gu, S., Zhao, X.Q., 2010. Seasonal variations in carbon dioxide exchange in an alpine wetland meadow on the QinghaiTibetan Plateau. Biogeosciences 7 (4), 1207-1221.

Zhou, X.H., Wan, S.Q., Luo, Y.Q., 2007. Source components and interannual variability of soil $\mathrm{CO}_{2}$ efflux under experimental warming and clipping in a grassland ecosystem. Glob. Change Biol. 13, 761-775.

Zhou, T., Shi, P.J., Hui, D.F., Luo, Y.Q., 2009a. Global pattern of temperature sensitivity of soil heterotrophic respiration $\left(Q_{10}\right)$ and its implications for carbon-climate feedback. J. Geophys. Res. 114, G02016. http://dx.doi.org/10.1029/ 2008JG000850.

Zhou, X., Zhao, Y., Liang, W., 2009b. Estimating the net primary productivity of grassland in poyang Lake wetland with a modified atmosphere-vegetation interaction model. Int. J. Geoinformat. 5 (2), 75-83.

Zhu, R.B., Liu, Y.S., Xu, H., Huang, T., Sun, J.J., Ma, E.D., Sun, L.G., 2010. Carbon dioxide and methane fluxes in the littoral zones of two lakes, east Antarctica. Atmos. Environ. 44 (3), 304-311. 